\title{
PHILOSOPHY
}

\section{Co-evolution of Society and Nature: Transformation of Cognitive Models}

\author{
E. A. Naumkina, S. V. Sumchenko \\ Sumy State Pedagogical University named after A.S. Makarenko (Sumy, Ukraine) $)^{1}$ \\ State Institution «Lugansk State Medical University» (Rubezhnoye, Ukraine) ${ }^{2}$ \\ Corresponding author. E-mail: Olena123@gmx.com ${ }^{1}$, svitlanasumchenko@gmail.com²
}

Paper received 29.08.20; Accepted for publication 20.09.20.

\section{https://doi.org/10.31174/SEND-HS2020-237VIII41-08}

\begin{abstract}
The article presents a philosophical and methodological analysis of the formation and change of cognitive models of understanding the phenomenon of co-evolution of society and nature. Attention is focused on the theoretical and methodological possibilities of the modern model of studying this phenomenon - synergetic.

Keywords: co-evolution of nature and society, an evolutionary model, an anthropo-ethnological model, a noospheric model, a synergetic model.
\end{abstract}

Introduction. One of the main directions of the postnonclassical stage in the development of science was the search for a new optimal strategy for the development of the «society-nature» system, aimed at harmonizing the relations between its main elements. This is due to the increasing probability of destruction of the foundations of human existence in the modern world. The rapid development of NBICS technologies, which equips humans with enormous opportunities for large-scale transformations of the biosphere, makes the existence of Homo Sapience more and more unstable, risky and problematic. This problem becomes especially urgent today, in the context of the Covid-19 pandemic, which once again has demonstrated the close interdependence of society and nature. When a person feels the real challenges of nature, there comes a special time of realizing the need to search for the new ways and mechanisms for maintaining balance in the «society-nature» system. Therefore, the appeal of philosophical thought to comprehending the phenomenon of co-evolution of society and nature (joint, coupled evolution) is due not only to cognitive, but above all, practical value: the need to prevent the threat of selfdestruction of mankind.

When analyzing the problem of coevolution in the «society-nature» system, the researchers encounter certain methodological difficulties, which are determined by the high degree of the complexity of this system, as well as a biosocial character, which is expressed in a person's belonging to two worlds - natural-evolutionary and culturalhistorical.

The reductionist-analytical approach of classical science to a certain extent ignored these features, which led to the loss of the ontological unity of man and nature, to the rupture of the corresponding elements of the global socio-natural system, to the appearance of the gaps in understanding their integrity and interdependence. The inconsistency, if not the explicit opposition of these aspects of human existence, called into question the further development of civilization.

This situation requires an increase of the theoretical and methodological levels of knowledge of the «societynature» system, as well as an increase of the predictive potential of theoretical research in order to develop the concept of optimal human interaction with the natural environment.

Analysis of relevant research. The first systematic studies of human interaction with nature were carried out within the framework of the evolutionary theory of Charles Darwin (E. Haeckel, T. Huxley, J. Herder, W. Humbolt, P. Kropotkin, J. Lamarck, I. Mechnikov, S. Podolinsky, N. Severtsov, K. Vogt, A. Wallace and others).

New ideas of the anthropo-ethnological concept have added the classical civilizational approach to human history. A significant contribution to its development belongs to L. Gumilyov, L. Morgan, P. Sorokin, G. Spencer, E. Taylor, A. Toynbee, O. Spengler and others.

The noospheric model for studying the problem of the co-evolution of society and nature has become widely known thanks to the works of V. Vernadsky, E. Leroy, P. Teilhard de Chardin and subsequently - M. Bulatov, V. Demin, V. Zagorodnyuk, V. Kaznacheev, N. Kiselev, V. Krisachenko, S. Krymsky, N. Moiseev, A. Ursula, O. Yanshin and others.

New opportunities in the study of the coupled evolution of society and nature are opening up today within the framework of post-classical science, the core of which is synergetics. We have found the constructive ideas regarding the synergetic mechanisms of coevolution of the socio-natural system in the studies of I. Prigogine, I. Stengers, E. Janch, Helga Weisz and Eric Clark [10], Jens Jetzkowitz [11], as well as I. Dobronravova, R. Karpinskaya, E. Knyazeva, L. Leskov, V. Lukyants, N. Moiseev, S. Moroz, A. Nazaretyan, S. Rodina and others.

The aim of the article is to trace the evolution of cognitive models for studying the phenomenon of the coevolution of society and nature, to identify their features and substantiate the constructiveness of the theoretical and methodological capabilities of the new synergetic model.

Materials and methods. In our research we have used the fundamental ideas of evolutionary, anthropoethnological, noospheric and synergetic concepts. The main methods of the study have been the critical-reflexive analysis of cognitive models of understanding the coevolution of society and nature, dialectical, systemic, comparative approaches, as well as a number of general 
logical research methods.

Results and their discussion. The phenomenon of coevolution of nature and society is comprehended using historically specific cognitive models or cognitive patterns. "Cognitive models are invariant structures that underlie the interaction and development of sciences at a particular stage of scientific knowledge, acting as a constructive means of cognitive activity, combining abstractness with visual-sign forms of representation, focused on identifying the stable, universal and necessary, setting a holistic view of the levels of organization of scientific knowledge, a method of posing problems, analytical units and a picture of the world for the scientific community at one stage or another in the history of science» [4, p. 250]. In relation to the scientific community, they act as a paradigm, forming models and rules for formulating and solving scientific problems.

Historically, the first cognitive model of the coevolution of society and nature was the evolutionary model, the founder of which is fairly considered Charles Darwin. A significant contribution to the development of this paradigm introduced by other researchers: Ernst Haeckel, Thomas Huxley, J. Herder, W. Humboldt, P. Kropotkin, Jean Lamarck, I. Mechnikov, S. Podolinski, N. Severtsov, A. Wallace, K. Vogt and others. Scientific comprehension of the integrity and interdependence of society and nature was begun precisely within the framework of the evolutionary approach.

As you know, for a long time a person was considered in the context of divine creation and thus was taken out of the framework of scientific reflection. In the middle of the eighteenth century K. Linnaeus introduced man into the system of nature, uniting him with the highest mammals in the same row - primates. This became the main prerequisite for the assertion of the naturalness of man, his inextricable connection with the organic world.

In evolutionism the question of the genesis of man as an integral part of nature was raised, a number of the patterns of this process were revealed (the role of heredity and variability as factors of evolution, the stabilizing and driving role of selection, adaptation as a development strategy and others). It has been noted that the mechanisms of their implementation in human society have their own specifics. "The evolutionary approach to human history made it possible, on the one hand, to extend its time frame far into the depths of the world that gave birth to man, into the organic world, with which he is genetically linked, on the other, - to highlight the exceptionality of the development strategy of this particular type of living creatures, to explore the unique adaptive mechanisms of self-organization of the system (species) with the help of culture, activity in a broad sense as a whole» $[6, \mathrm{p}$. 628].This cognitive model made it possible to consider two aspects of human existence in unity and interdependence, which, to a certain extent, contributed to overcoming the abyss in their understanding. Therefore, the evolutionary model of the study of the problem of coevolution is productive in that part of it, where the adaptive mechanisms of self-organization of society are considered as certain integrity, inextricably linked with its natural environment, as well as the uniqueness of human development due to the specificity of its adaptive mechanisms.

The evolutionary style of thinking had a huge impact on the development of all subsequent science. Currently, the evolutionary model is used in almost all areas of scientific knowledge and demonstrates its effectiveness.

Within the framework of the classical civilizational approach to human history, taking into account the new achievements of theoretical and methodological reflection, an anthropo-ethnological concept was proposed (L. Gumilev, L. Morgan, P. Sorokin, G. Spencer, E. Taylor, A. Toynbee, O. Spengler and others), which supplemented the studies of the co-evolution of society and nature with the study of various cultures, traditions, values of human communities. The most famous interpretations are L. Gumilyov's passionate theory of ethnogenesis, the well-known concept of the relationship between society and the environment according to the principle of Challenge - and - Answer of the British philosopher and historian A. Toynbee.

L. Gumilyov's passionate theory of ethnogenesis is based on the concept of ethnos as a biosphere phenomenon, which is closely related to the landscape. History appears as a socio-natural process that follows natural laws. «Ethnogenesis», L. Gumilev writes, «is a natural process, fluctuation of the biochemical energy of the living matter of the biosphere. An outburst of this energy - a passionary impulse occurring in a particular region of the planet - generates movement...» [3, p. 26]. Passionarity is manifested in the fact that individuals who have acquired it strive for some kind of activity related to the achievement of the intended goal. Moreover, this goal can be both reasonable and useful, and destructive, including in relation to the environment. As a result of the migration of passionaries, a so-called «chimeric ethnos» (an inharmonious combination of several elementary ethnic groups with different moral, axiological guidelines, and practice of nature management) may arise. This situation, as a rule, leads to negative consequences in the relationship between society and nature. Over time a chimeric ethnos can develop new regulatory mechanisms for improving its relationship with the environment. However, this process is very long and burdensome for both nature and mankind.

Thus, the model of ethnogenesis in a certain sense makes it possible to identify both the causes of the destruction and degradation of natural ecosystems and the conditions for the harmonious development of society and the environment, indicating the need to take into account both the natural and sociocultural components of human existence.

The noospheric model for studying the problem of coevolution of society and nature, based on the principles of the unity of man and the Cosmos, and their coordinated development, is quite well-known. This cognitive model was developed both in the religious (Teilhard de Chardin [9]) and in the natural sciences (V. Vernadsky). Despite the differences in views, the researchers have been characterized by the assertion that man is only a part of a more general unified system with which he is in deep interconnection, and at a certain stage a man must take responsibility for the further evolution of the biosphere.

We are interested in the approach to the problem of the noosphere by V. Vernadsky, who believed that «under the influence of scientific thought and human labor, the biosphere passes into a new state - the noosphere» [2, p. 27], 
that is, the noosphere is a process of transformation of the biosphere itself, which humanity has yet to provide. In this respect V. Vernadsky's position differs significantly from Teilhard de Chardin's. Since the noosphere is a special state of the biosphere, it is absurd to talk about the creation of the noosphere outside the framework of the biosphere. This implies an important conclusion that the sustainable development of the «society-nature» system is possible only if the biosphere's identity is preserved. Nature, society, science appear in V. Vernadsky's studies as interconnected and interdependent entities.

Despite the ambiguity of understanding and assessing the concept of noospheric development, it must be admitted that this cognitive model contains many constructive ideas (especially its natural science interpretation). It supplemented the previous models with a new understanding of the place and role of man in the global socionatural system, making him responsible for the further evolution of the biosphere. It enriched the modern methodology with one of the key ideas - the idea of integrating scientific knowledge. And the further development of science has convincingly confirmed the potential of this approach. As V. Borzenkov has noted, «the emergence in the last third of the twentieth century of a whole fan of scientific directions with the prefixes «bio» and «evolutionary» (bioethics, bioesthetics, biolinguistics, biohermeneutics, etc., evolutionary ethics, evolutionary epistemology and so on) testifies about the presence of a real «bridge» between genetic-organic and socio-cultural evolution and building on this basis of «bridges» between natural (biological) and social and humanitarian sciences» [1, p. 307].

Consequently, today there is a considerable methodological and theoretical potential for studying the problem of the co-evolution of society and nature. However, humanity in its relations with the environment and in its self-development is increasingly beginning to feel the effects of disequilibrium, nonlinearity and unpredictability. Therefore, the old cognitive models based on the principles of linearity and classical determinism demonstrate a clear discrepancy and a certain limitation of their cognitive means, this actualizes the search for new theoretical and methodological approaches to this problem within the framework of the modern scientific picture of the world.

The development of post-non-classical science is characterized by the formation of a synergetic cognitive model, the subject of which is the processes of selforganization in complex nonlinear systems of various nature. According to V. Lukyants, her explanatory schemes are quite effective in understanding the coevolution of man and nature, since «the new, that is Prigogine's, philosophy of nature comprehends nature as an element of various systems with complex behavior. In a state of equilibrium, it is passive; its behavior does not differ from the behavior of those linear, deterministic systems that are investigated in classical science. Far from equilibrium, it becomes active (as if «obstinate», "selfwilled»); here its dynamics differs sharply from the dynamics of linear, deterministic systems. Thus, the new philosophy of nature does not reject the old one, but limit the scope of its applicability» [8, p. 73].

Synergetics, from a philosophical point of view, stud- ies being that arises, the mechanisms of its formation. A formation, in another interpretation - this is the crisis of the system. Synergetics proceeds from the idea that a crisis is a bifurcation state of the system, from which there are several ways out. This means that any complex system has a certain range of alternative development paths. It is important that synergetics is able to formulate some evolutionary rules of prohibition, that is, what, in principle, cannot happen in a certain complex system, which is not inherent in it. Knowing the limitations of what, in principle, cannot be realized is pretty constructive knowledge. Such an approach, according to L. Leskov, will make it possible to abandon the search for answers to the traditional question «What is to be done?» in favor of another, more promising «What not to do?». In other words this means that the analysts have in their hands the method of a priori determination of the criteria for prohibiting blind corners and non-optimal scenarios [7, p. 56].

It should be admitted that synergetics does not provide specific recommendations for the implementation of a specific possible future option. It outlines general guidelines for scientific research, for forecasting and modeling the processes that take place in complex systems. Today, the reliability of forecasts depends on how adequate models of bifurcation mechanisms will be developed. A formal description of such models with the participation of many random factors is given, as a rule, in the form of a spectrum of possible scenarios. Therefore, in the bifurcation zone, only a probabilistic forecast can be made: either to stay on the given evolutionary trajectory of development or to move into possible new states.

S. Kurdyumov and E. Knyazeva believe that we have no right to passively wait for the future. We must become the creators of the desired future. In nonlinear situations of disequilibrium, a person can play a decisive role in the choice of the desired future structure and, at the same time, the one that is realizable from the spectrum of possible attractors. To do this we must learn to determine the range of attractors of the complex systems and the boundaries between the areas of their attraction. A person can build the present from the future. However, this is rather difficult, since there is a problem of coordinated purposeful action of the synergistic mechanism of neoplasms, which takes place in conditions of disequilibrium, and the cybernetic mechanism of stabilization of the current state of the global socio-natural system.

A guided transition to a new attractor is carried out on the basis of the following rules:

- the control action must resonate with the internal development trends of the self-organizing system;

- in a non-equilibrium state, non-force interactions begin to play an important role: insignificant, but coordinated with the internal potentials of the system, actions turn out to be more effective than significant ones;

- the control action should be carried out gradually, step by step on the basis of fuzzy adaptive control [5].

A man, knowing the mechanisms of self-organization, can consciously introduce appropriate fluctuations into the system and thus direct development not anywhere, but in accordance with the potential capabilities of the object. It should be taken into account that mistakes in the strategic management of non-equilibrium systems pose a great 
danger, since there are always new formations of a catastrophic orientation, which can become dominant under conditions of inadequate management. In this regard, humanity will have to carefully calculate the possible consequences of its interference in the processes that take place in the global socio-natural system. That is why postnon-classic science devotes a special role to valueoriented research attitudes. Bioethics makes a significant contribution to the development of this area of modern science and the study of the co-evolution of society and nature.

The conclusions. The synergetic model, making ex- tensive use of the concepts and conceptual structures of previous models, transforms and supplements them with new principles: nonlinearity, irreversibility, randomness as a constructive factor of evolution. It opens up new opportunities for deeper understanding of the fundamental laws of the development of society and nature and the organization of the directed evolution of the global socionatural system. Therefore, the use of the ideological and methodological potential of this cognitive model in understanding the phenomenon of co-evolution of society and nature, in our opinion, is quite promising and productive, but requires further development.

\section{ЛИТЕРАТУРА}

1. Борзенков В.Г. Биофилософия в преодолении раскола двух культур // Философия и будущее цивилизации: тезисы докладов и выступлений IV Российского философского конгресса (Москва, 24-28 мая 2005г.): В 5 т. Т.1.М.: Современные тетради, 2005. С. 306-307.

2. Вернадский В.И. Философские мысли натуралиста. М.: Наука, 1988. $520 \mathrm{c}$.

3. Гумилев Л.Н. Из истории Евразии. М.: Наука, 1993. 208 с.

4. Карпинская Р.С., Лисеев И.К., Огурцов А.П. Философия природы: коэволюционная стратегия. М.: Интерпракс, $1995.350 \mathrm{c}$.

5. Князева Е.Н., Курдюмов С.П. Синергетика и принципы коэволюции сложных систем http://spkurdyumov.ru/evolutionism/sinergetika-i-principykoevolyucii-slozhnyx-sistem/

6. Крисаченко В.С. Людина і біосфера: основи екологічної антропології. К.: Заповіт, 1998. 688 с.

7. Лесков Л.В. Философия нестабильности // Вестник Московского университета. Серия 7. Философия. 2001. № 3. C. $40-61$.

8. Лукьянец В.С. Философия природы: новые мировоззренческие рубежи // Философия природы и практическая философия. Материалы конференции. Киев, 2004. С. 71 79.

9. Тейяр де Шарден П. Феномен человека. М.: Наука, 1987. $240 \mathrm{c}$

10. Helga Weisz, Eric Clark. Society-nature coevolution: Interdisciplinary concept for sustainability. Geografiska Annaler. Series B. Human Geography 93(4): P. 281-287. December 2011.

11. Jens Jetzkowitz. Co-Evolution of Nature and Society: Foundations for Interdisciplinary Sustainability Studies Springer Nature Switzerland AG Cham, Switzerland. 2019. 233p.

\section{REFERENCES}

1. Borzenkov V.G. Biophilosophy in overcoming the split of two cultures // Philosophy and the future of civilization: abstracts of reports and speeches of the IV Russian Philosophical Congress (Moscow, May 24-28, 2005): In 5 volumes. Vol.1. M.: Modern notebooks, 2005. P. 306-307.

2. Vernadsky V.I. Philosophical thoughts of a naturalist. Moscow: Nauka, 1988. 520 p.

3. Gumilev L.N. From the history of Eurasia. Moscow: Nauka, 1993. 208 p.

4. Karpinskaya R.S., Liseev I.K., Ogurtsov A.P. Philosophy of Nature: Co-evolutionary Strategy. M.: Interpraks, 1995. 350 p.

5. Knyazeva E.N., Kurdyumov S.P. Synergetics and principles

of coevolution of complex systems http://spkurdyumov.ru/evolutionism/sinergetika-i-principykoevolyucii-slozhnyx-sistem/

6. Krisachenko V.S. Man and the biosphere: basics of ecological anthropology. K.: Testament, 1998. 688 p.

7. Leskov L.V. The philosophy of instability // Bulletin of Moscow University. Series 7. Philosophy. 2001. No. 3. P. 40-61.

8. Lukyanets V.S. Philosophy of nature: new world outlook boundaries // Philosophy of nature and practical philosophy. Conference materials. Kiev, 2004. P. 71-79.

9. Teilhard de Chardin P. Phenomenon of man. Moscow: Nauka, 1987. $240 \mathrm{p}$. 